\title{
ZOOPLANKTON SPATIAL DISTRIBUTION AND COMMUNITY STRUCTURE IN BANGGAI SEA
}

\author{
Arief Rachman and Elly Asniariati \\ Research Center for Oceanography, Indonesian Institute of Sciences \\ Jl. Pasir Putih I, Ancol Timur, Jakarta Utara. Email: red_rackham_dead@yahoo.com
}

\begin{abstract}
Banggai Sea is an interesting ecosystem due to mixing influences from Banda Sea in the west and Maluccas Sea in the east. Therefore, a unique zooplankton community structure and specific distribution pattern should be found in this area. This research was carried on using Baruna Jaya VIII research vessel and samples were collected in 14 sampling stations. Vertical towing using NORPAC plankton net $(300 \mu \mathrm{m})$ was conducted to collect zooplankton samples. Result showed that inner Mesamat Bay had the lowest abundance of zooplankton, probably due to low water quality resulted from anthropogenic activity. Meanwhile the strait between Liang and Labobo Island had the highest zooplankton abundance in Banggai Sea. Calanoids was the dominant zooplankton taxa in the ecosystem and contributing $55.7 \%$ of total density of zooplankton community. The highest importance value made this taxa to be very important factor that regulates the lower trophic level organisms. Results also showed that zooplankton was distributed nearly uniform in eastern but aggregated to several stations in western Banggai Sea. Zooplankton abundance was higher in the central of Banggai Sea, compared to western and eastern area. According to Bray-Curtis clustering analysis the strait between Liang and Labobo Island has unique zooplankton community structure. This might happened due to mixing of water from two highly productive seas that influenced the Banggai Sea ecosystem. From this research we conclude that this strait probably was the zooplankton hot spot area which might also indicate that this area also a hot spot of fishes in the Banggai Sea.
\end{abstract}

Keywords: spatial distribution, zooplankton, community structure, hot spot, Banggai Sea.

\section{INTRODUCTIONS}

One characteristic of planktonic population, including zooplankton population, is that they tend to form patches that vary on a scale of few meters to hundreds of kilometers (Nybakken and Bertness, 2005). This patch occurs due to influence of many physical and chemical parameters in the water. The most common water parameters that regulating this patchiness in marine ecosystems are dissolved oxygen, temperature, salinity, turbidity, $\mathrm{pH}$ and water movement (Horne and Goldman, 1994; Nybakken and Bertness, 2005; Hsiao et al., 2011). Thus large-scale patchiness that occur in marine ecosystem might happened due to changes in the stability of water column, resulting in changes in nutrient availability for plankton in the ecosystem (Nybakken and Bertness, 2005; Escribano et al., 2005). Most of zooplankton organisms are sensitive to fluctuation in water parameters, thus it inducing changes in abundance and also regulate the distribution of various zooplankton genuses in the ecosystems (Hsiao et al., 2011). Zooplankton also tends to form clump or patch of high density population at areas with high phytoplankton 
abundance (Nybakken and Bertness, 2005).

Banggai Sea is heavily influenced by Banda Sea and Moluccas Sea, two productive seas in Indonesia due to seasonal upwelling event (Asriyana dan Yuliana, 2012). Both Banda Sea and Moluccas Sea were part of Indonesian Throughflow (ITF) system which connecting the water masses between Pacific Ocean and Indian Ocean (Gordon and Susanto, 2001; Sprintall et al., 2009). Mix of waters from those seas not only resulting in high diversity of marine organisms in Banggai Island, it also sustain various types of ecosystems such as mangrove forests, marine dominated estuaries, coral reefs and seagrass bed. Monsoon system that heavily affected the condition of Banda Sea and Moluccas Sea (Baars et al., 1990; Gordon and Susanto, 2001), might also affecting the condition of water parameters in Banggai Sea. The mix of water masses from Banda Sea and Moluccas Sea should affect the zooplankton community structure and spatial distribution in Banggai Sea. It was hypothesized that the mixing area in Banggai Sea should become the center of zooplankton abundance and probably has different community structure compared to Banda Sea and Moluccas Sea. The aims of this research are to understand the community structure and spatial distribution pattern of zooplankton in Banggai Sea related to with the phytoplankton community in the ecosystem.

\section{METHODS}

\subsection{Study Sites}

Banggai Sea was a part of Banggai Island archipelago which located eastern from South Celebes (Figure 1). This area was known for its high diversity in marine organism and marine ecosystems, such as marine dominated estuaries, mangrove forests, coral reefs, seagrass beds and coral reefs. Oceanic atolls and wide reef flat was found in Karang Merpati and known as hotspot for fish diversity in Banggai Sea. The water of Banggai Sea was a mix of water masses from two highly productive seas, the Banda Sea and Moluccas Sea. This condition created a high productive water thus creating several area which known as hot spot for fisheries in Banggai Sea. There are 7 islands that surrounding Banggai Sea, which were Liang, Tinangkung, Banggai, Lo Bangkurung, Labobo, Melilis and Timpaus (Figure 1).

\subsection{Field Sampling}

This research was conducted using Baruna Jaya VIII, a research vessel belongs to Research Center for Oceanography, Indonesian Institute of Sciences during Banggai Island Expedition in 16 June - 8 July 2011. Plankton sample was taken in 14 sampling stations around Banggai Sea (Figure 1) during night time. Zooplankton sampling was done with vertical towing method using NORPAC plankton net (mouth 0.45 $\mathrm{m}$; length $1.8 \mathrm{~m}$; mesh $300 \mu \mathrm{m}$ ). Flowmeter was attached in the mouth of plankton net to measure volume of filtered water, using formula as described by Arinardi in Hutagalung et al. (1997).

In this research most sampling was done from depth of $200 \mathrm{~m}$, although in some shallow areas sample was collected from depth of $20,60,70,80$ or $150 \mathrm{~m}$. After each towing, plankton net was soaked with seawater to release some zooplankton that trapped in the net. Filtered zooplankton sample was collected in $250 \mathrm{ml}$ polyethylene bottle and fixated with $4 \%$ formaldehyde. 


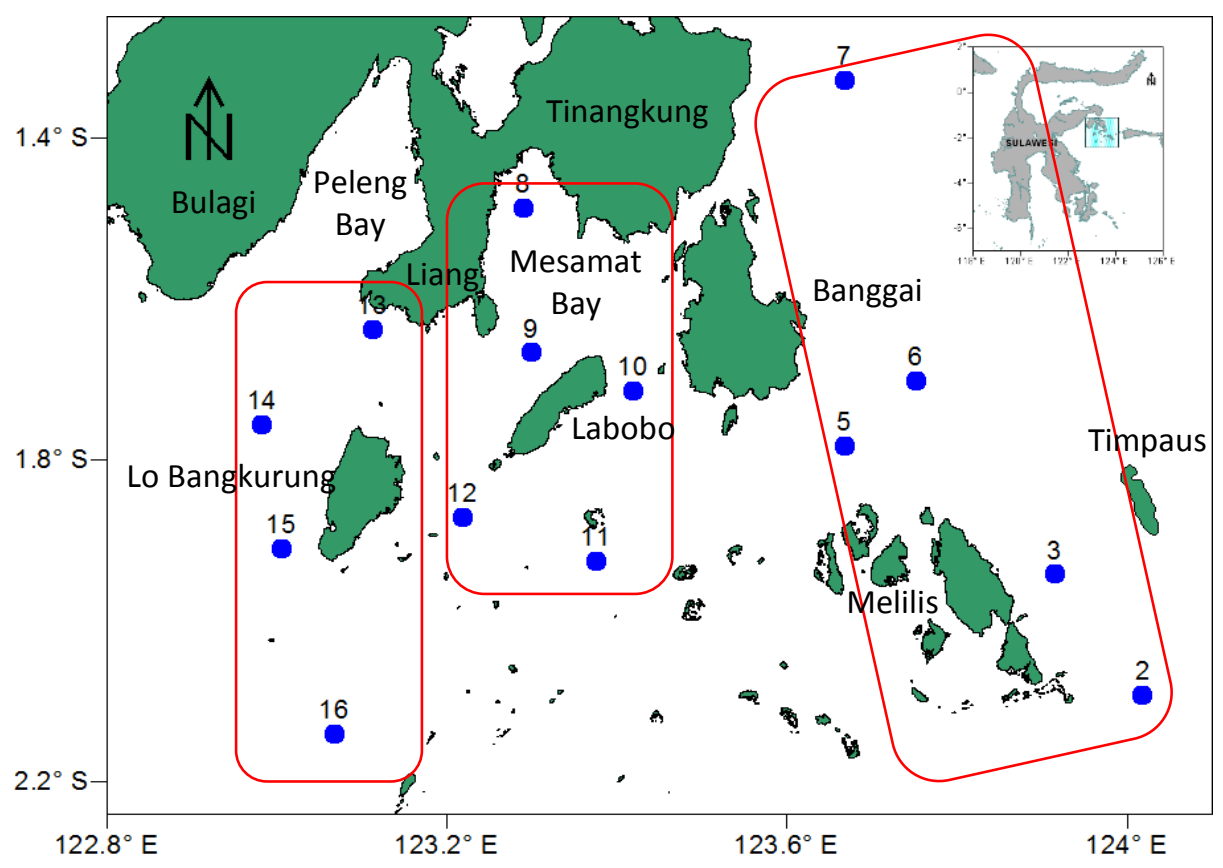

Figure 1. Map of Banggai Sea and the location of sampling stations in this research. The sampling stations divided into western, middle and eastern zone of Banggai Sea.

\subsection{Zooplankton Identification and Enumeration}

Zooplankton identification and enumeration was done in Plankton and Primary Productivity Laboratory, Research Center for Oceanography, Indonesian Institute of Sciences. Identification and enumeration of zooplankton individuals was done by conducting fraction method, taken with $2.5 \mathrm{ml}$ stample pipette. Fractioned sample was then placed in Bogorov counting tray and observed using LEICA MZ-6 stereo microscope under 4 - $40 \mathrm{X}$ magnification. Identification was done up to genus level using references from Shirota (1966), Yamaji (1966), Nontji (2000), Wickstead (1976). Estimation of zooplankton individual in the sample was done by using formula as described by Semina in Sournia (1978).

\subsection{Data Analysis}

The data was analysis by generating biotic parameters, such as absolute density, relative density, absolute frequency, relative frequency and importance value of all zooplankton taxa in Banggai Sea (Cox, 1976). The data was also analyzed with Shannon-Wienner indices of diversity, simple regression and correlation. A contour map representing pattern of zooplankton abundance was created using Surfer ver. 8.0 Surface Mapping System, to understand the spatial distribution pattern of zooplankton in Banggai Sea. Bray-Curtis Cluster Analysis (Simple Average Link) was conducted using BioDiversity Provessional Ver. 2 to understand the trend of different zooplankton community structure in the sampling stations (McAleece et al., 1997).

\section{RESULTS AND DISCUSSIONS}

\subsection{Zooplankton Community Structure in Banggai Sea Ecosystem}

From this research it was found that calanoids was the dominant taxa in the zooplankton community of Banggai Sea. The density of calanoids found in the 
water column of Banggai Sea was 6,119 ind. $\mathrm{m}^{-3}$ and contributing $55.70 \%$ to total number of zooplankton in the community (Fig 2A and 2B). Calanoids was found widely distributed in the Banggai Sea and could be found in all sampling stations in this research (Figure 2C).

Based on importance value analysis, calanoids has the highest importance value, thus making this taxa have a significant role in the zooplankton community of Banggai Sea (Figure 2D). High abundance of calanoids in the water column was common in tropical oceanic ecosystem, such as in Southwestern Atlantic and West Africa (NeumannLeitao et al., 2008; Champalbert et al., 2005).

Aside from calanoids, cyclopoids was found have the second highest density (Figure 2A and 2B) and have importance value of $15.19 \%$ (Figure 2D). These taxa were also widely distributed in Banggai Sea and could be found in all sampling stations (Figure 2C). This pattern of widely distributed copepods, indicating that circum-global distribution pattern was more common than endemism in Banggai Sea. This might also related to the lack of freshwater runoff from the islands around the study area, because of the season or the basic geomorphology of the area (Neumann-Leitao et al., 2008). The other zooplankton taxa that have high abundance in this research were oikopleurans, ostracods and chaetognathes (Figure 2A and 2B). These three taxa were also have relatively high importance value in the community compared to other zooplankton taxa in this research (Figure 2D). The importance value of oikopleurans, ostracods and chaetoghanthes were $14.25 \%, 11.75 \%$ and 9.35\% respectively. Relatively high abundance of ostracods in this research was characteristic for oceanic environment in oceans (Riandey et al., 2005).

From this research it also found that the abundance of macro-crustaceans, such as mysids and brachiopods, were very low compared to other zooplankton taxa (Figure 2A and 2B). Both taxa were only found in one station in this research, thus making mysids and brachiopods have quite low frequency (Figure 2C). This result indicating that the distribution of brachiopods and mysids in Banggai Sea were very limited to some stations, which have the most suitable water parameter for those two taxa. It assumed that brachiopods and mysids found in this research has narrow tolerance range, thus changes in water parameters would limit their spatial distribution.

\subsection{Zooplankton Spatial Distribution in Banggai Sea}

A distinct pattern of different zooplankton density was found in sampling station belong to three zones of Banggai Sea (Figure 3). In general, the middle zone of Banggai Sea holds the highest mean zoooplankton abundance compared to two other zones (Figure 3B). Figure 3A showed that station 9, which is a strait between Labobo and Liang (Figure 1), has the highest zooplankton abundance, with density of 1,722 ind. $\mathrm{m}^{-3}$. Meanwhile station 8 that located in the inner Mesamat Bay, has the lowest zooplankton abundance (Fig 3A), despite of it location which inside a large bay and near the coast of the largest island in Banggai Sea (Figure 1). The density of zooplankton individuals in station 8 was only 339 ind. $\mathrm{m}^{-3}$ (Figure 3A). This station should have high abundance of zooplankton due to high influence of land run-off or local topographic upwelling which enriches the water column (Neumann-Leitao et al., 2008). 

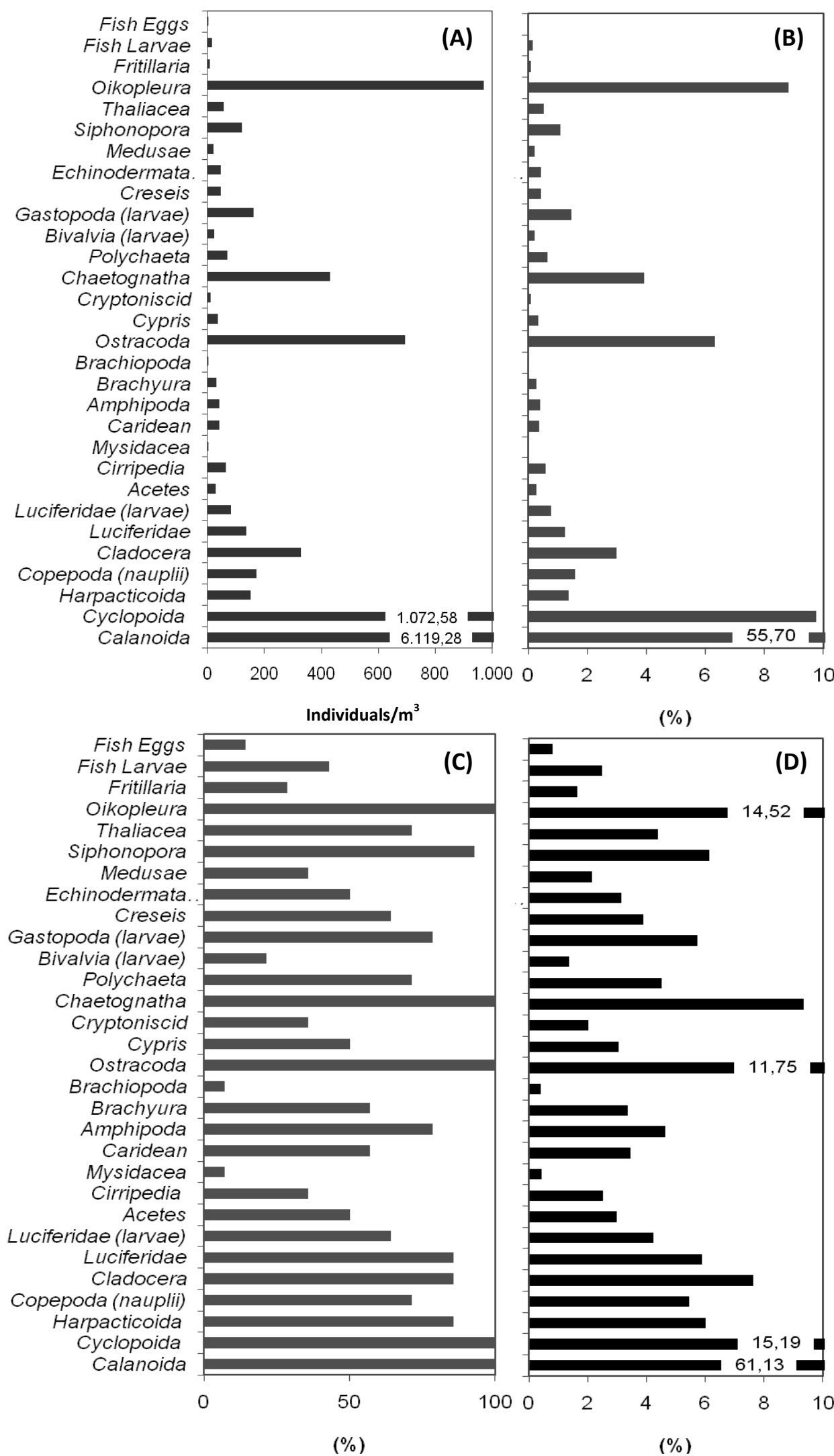

$(\%)$

$(\%)$

Figure 2. Zooplankton community structure of Banggai Sea ecosystem. (A) absolute density; (B) relative density; (C) frequency; and (D) importance value. 

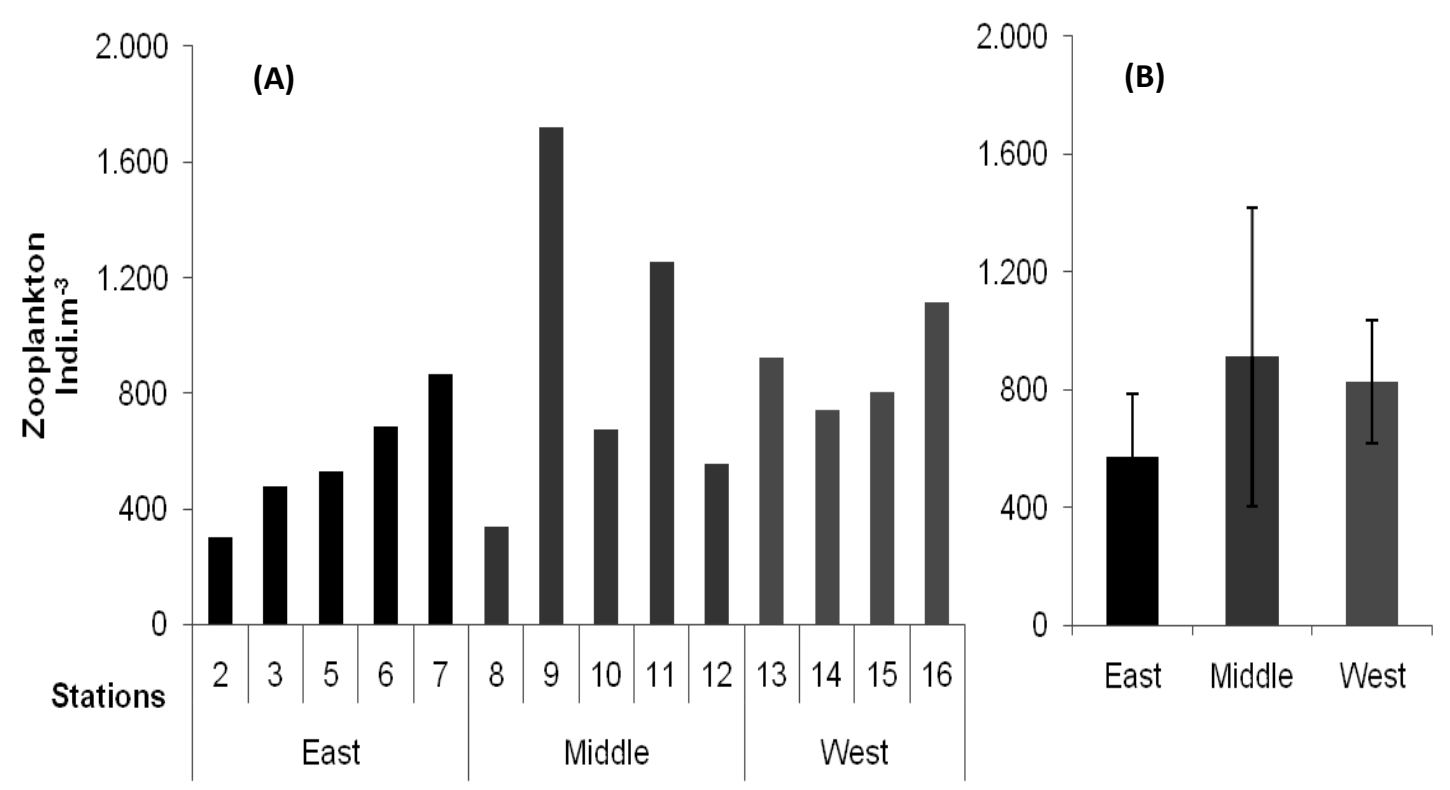

Figure 3. Zooplankton abundance in the sampling stations around Banggai Sea. (A) zooplankton absolute density in each sampling station; (B) average zooplankton density in three zones of Banggai Sea

The contour map of zooplankton abundance in Banggai Sea clearly showed that zooplankton abundance was centered on station 9 (Figure 4). This area could be designated as the hot spot zone for zooplankton distribution in Banggai Sea (Figure 4). This result also showed different trend of zooplankton patchiness in three zones of Banggai Sea. It was clear that stations in the middle zone of Banggai Sea have higher abundance of zooplankton compared to stations in the eastern and western zone (Figure 4).

The zooplankton population showed high patchiness in the middle area, with center of distribution located at station 9, 12 and 11 (Figure 4). Meanwhile the eastern zone, which heavily influenced by water mass from Moluccas Sea, seems to have homogenous zooplankton spatial distribution (Figure 4). This trend indicating that the water condition of eastern zone of Banggai Sea probably much more homogenous compared to two other zones, especially the middle zone. The relatively homogenous condition of water column in this research is a common characteristic of oceanic environment or region (Rakesh et al., 2006).

Further analysis on distribution pattern of zooplankton diversity in the Banggai Sea showed different patchiness pattern (Figure 5). Station 9 which has the highest abundance of zooplankton (Figure 4) was not the area with the highest value in Shannon-Wienner diversity indices (Figure 5). From Figure 5 it was clear that station 10 was the area with the most diverse zooplankton taxa in the Banggai Sea, with the value of 1.89 . Based on this result, it was clear that station 8 is the area with the lowest diversity of zooplankton in Banggai Sea, with the value of 1.27 (Figure 5). This similar pattern also observed in the contour map of zooplankton abundance in the waters of Banggai Sea (Figure 4). 


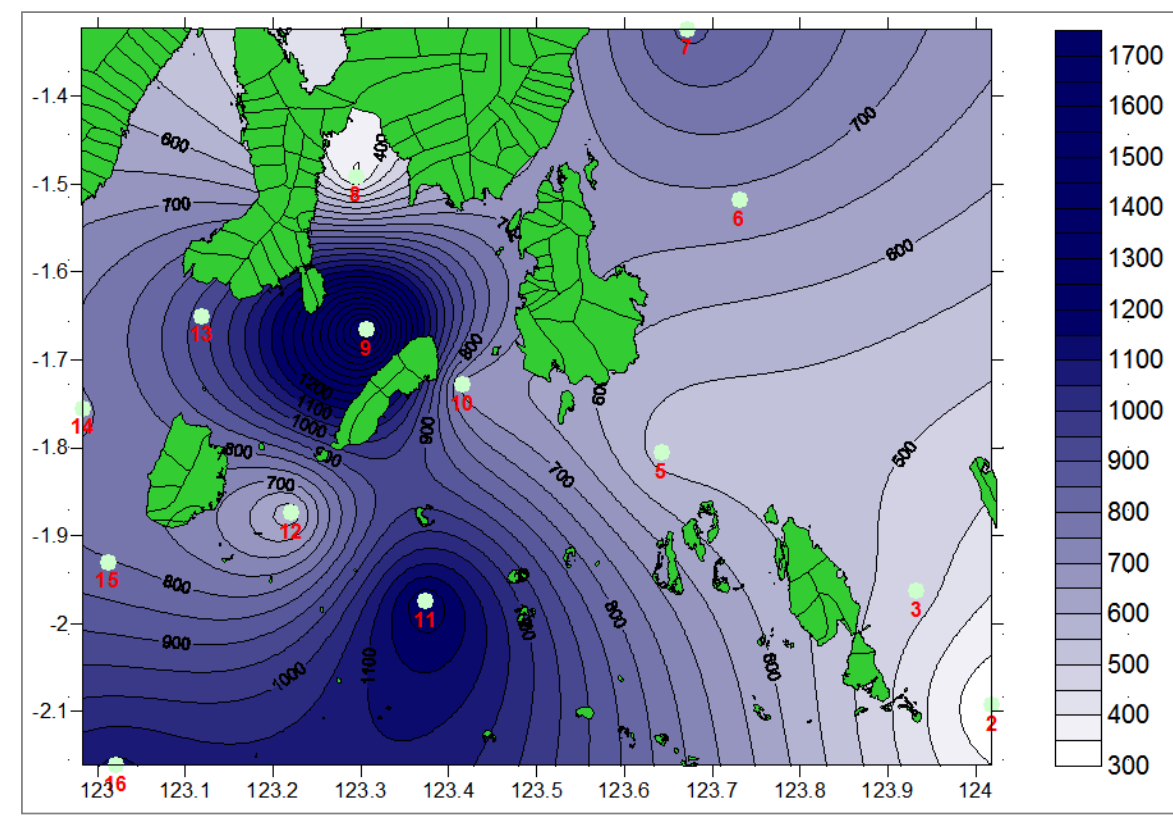

Figure 4. Contour map of zooplankton abundance in Banggai Sea, which also give clues to the trends in zooplankton spatial distribution and patchiness.

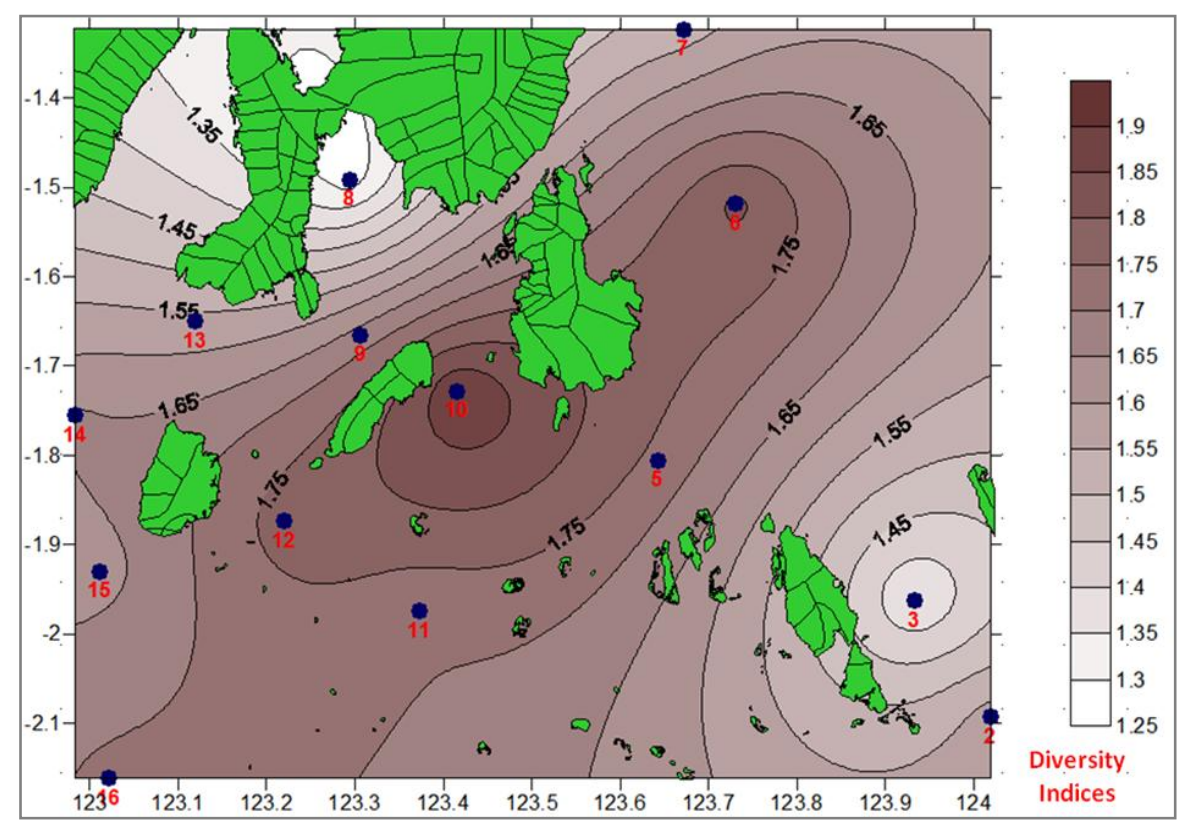

Figure 5. Contour map of zooplankton Shannon-Wienner indices of diversity. Different trend of zooplankton patchiness was observed from the result of this analysis.

3.3. Grouping of Sampling Stations Based on Zooplankton Community Structure

Bray-Curtis cluster analysis suggested four groups that were different from the each other's (Figure 6). It suggested that there were at least four unique zooplankton community structures in the Banggai Sea ecosystem. The similarity of community structure in each group was probably occurred due to similar condition of water parameters in the stations inside the group. 


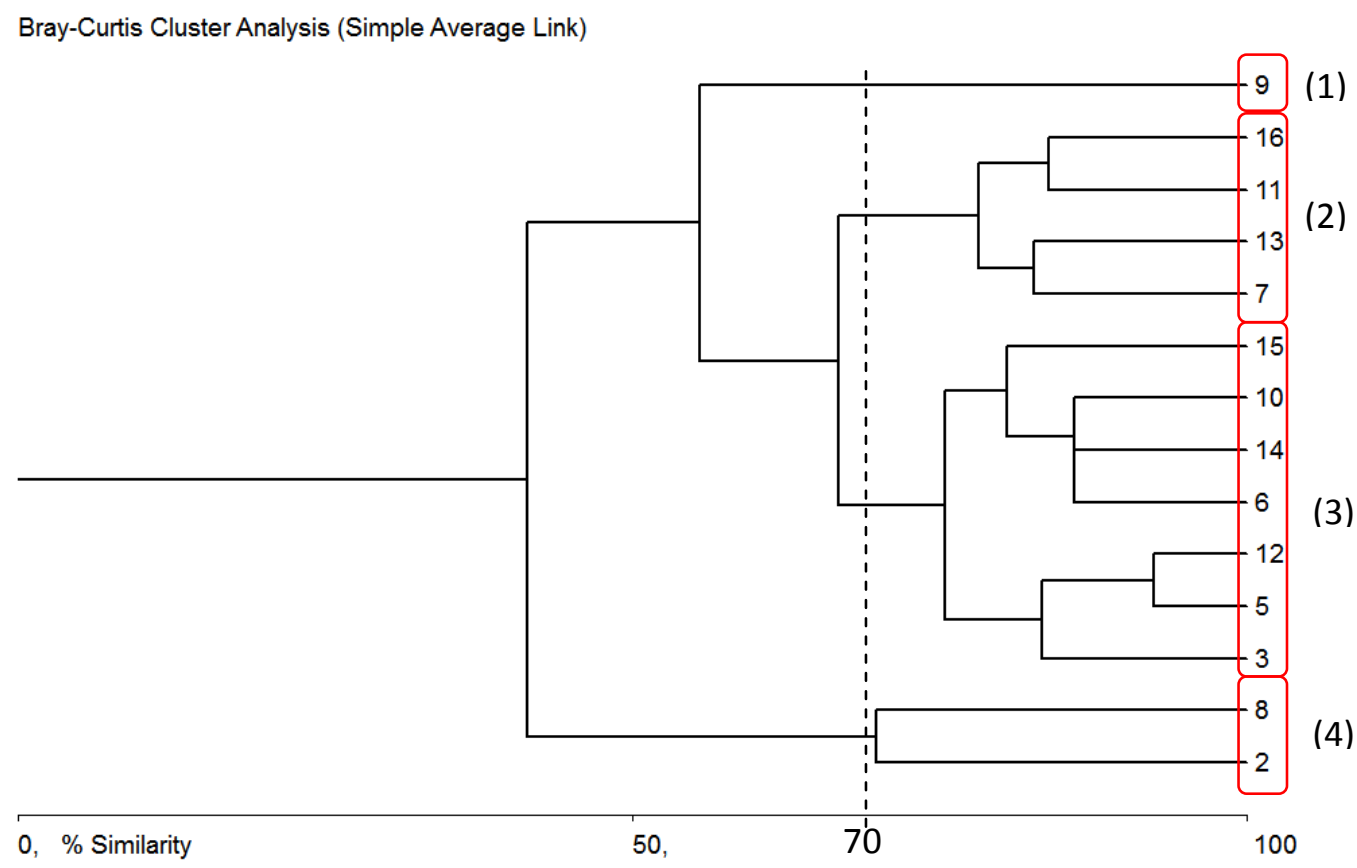

Figure 6. Dendogram resulted from Bray-Curtis cluster analysis of zooplankton community structure in each sampling station. Station 2, 3, 5, 6, 7 located in eastern area; Station 8, 9, 10, 11, 12 located in middle area; Station 13, 14, 15,16 located in western area.

Surprisingly the community structure of the sampling stations in this research showed no significant differences between three zones in Banggai Sea (Figure 6). It was assumed that zooplankton abundance and community structure in the middle zone's sampling stations were different from eastern and western zone. But in this result, it was clear that group 3 consist of stations that located at three different zones in this research (Figure 6). In group 3 (Figure 6), station 15,14 and 12 located at western zone, meanwhile station 3, 5 and 6 located at eastern zone of Banggai Sea (Figure 3 and 4). In general, this trend indicating that there were no significant differences in zooplankton community structure among the western, middle and eastern area of Banggai Sea. Although the results also showed that the spatial distribution (Figure 4) and the abundance (Figure 3) of zooplankton was different in those areas.

\subsection{Zooplankton Patchiness in Banggai} Sea

High patchiness of zooplankton population (Figure 4), high diversity (Figure 5) and high variation of zooplankton abundance (Figure 3A) in the middle zone of Banggai Sea, indicate that the water condition was heterogeneous. On the other hand, the most suitable condition for high population growth of zooplankton was only available in limited areas, such as station 9, 11 and 12. This condition might be happened due to mixing of different water masses from Moluccas Sea and Banda Sea which influence the Banggai Sea ecosystem.

Highly aggregated zooplankton patchiness in the water could occur due to mixing and upwelling event in the water column (Escribano et al., 2005). The water from those two productive seas might carry nutrients that mixed together in the middle zone of Banggai Sea, thus enriching the water and increase the 
primary production. In the end this condition was favorable for zooplankton and supporting the growth of its population. Station 9, which become the hot spot for zooplankton abundance in this research, was located in the strait between two islands (Figure 1 and 4) and probably also located in the mixing zone.

The present of coastal front or shelf break in station 9 might created vertical turbulence or upwelling events when two water masses from Moluccas and Banda Sea meets. This will enrich the water column with nutrients that support high phytoplankton growth, and then support high zooplankton growth in the water column (Nybakken and Bertness, 2005; Neuman-Leitao et al., 2008; Champalbert et al., 2005). Another indication of relatively high upwelling events in Banggai Sea was the frequent occurrence of harpacticoids, the commonly benthic copepods. In this research harpacticoids could be found at 12 sampling stations, except at station 2 and 14 .

Aside from the effect of physical factor, it assumed that the pattern of zooplankton patchiness in Banggai Sea was related to distribution of phytoplankton in the waters. When the data of zooplankton abundance in each station was combined with phytoplankton abundance, it was noted that at some point, there are similarity in the trend (Figure 7).

Although inconsistency was found in the term of station with the highest abundance in phytoplankton and zooplankton, the station with the lowest abundance remains the same, which is the station 8 (Figure 7). Very low abundance of phytoplankton might be the main reason for the low abundance of zooplankton in station 8. Unfortunately it is unknown why the high abundance of zooplankton in station 9 seems unrelated with the abundance of phytoplankton in adjacent station (Figure 7). Simple correlation analysis showed low positive relationship between zooplankton and phytoplankton in Banggai Sea, but this correlation was statistically insignificant ( $\mathrm{r}$ $=0.1292 ; \mathrm{p}>0.05)$. The simple linear regression showed a trend that an increase in phytoplankton abundance should be followed by an increase in zooplankton abundance (Figure 8).

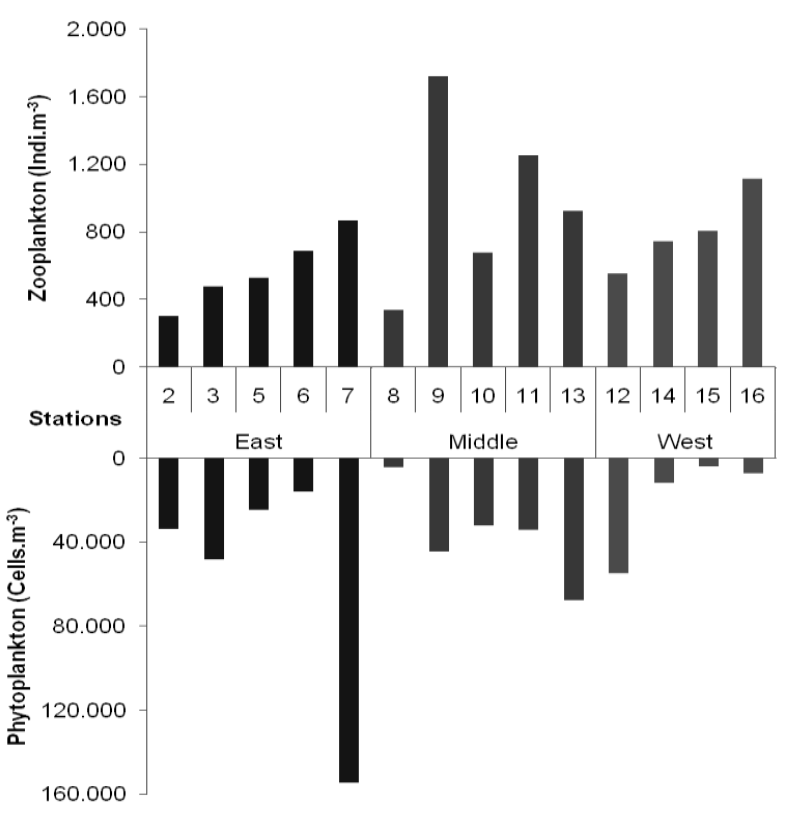

Figure 7. Combined histogram of zooplankton abundance and phytoplankton abundance in the Banggai Sea. 


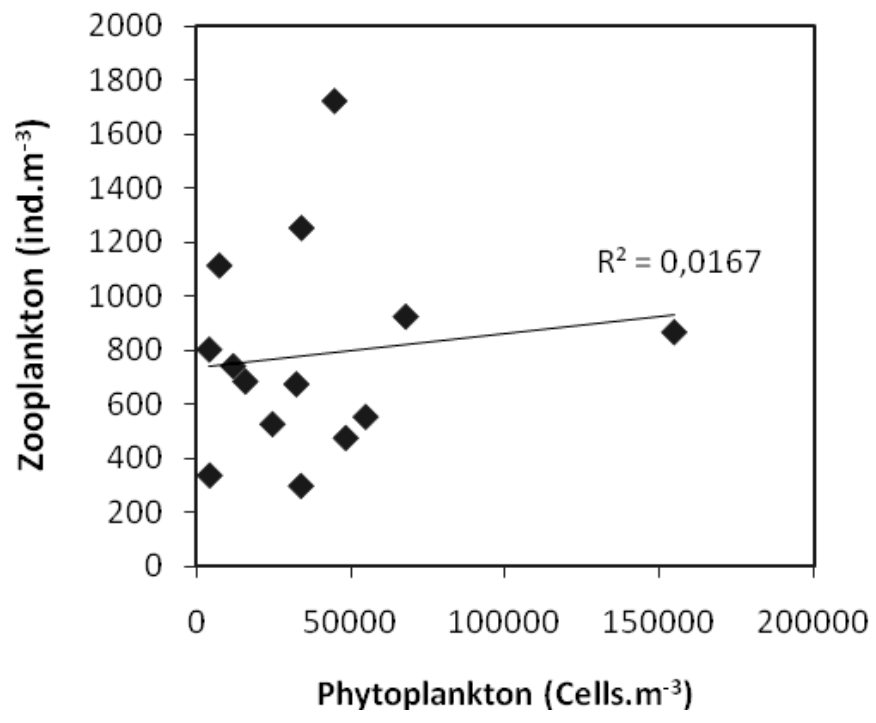

Figure 8. Regression graphic of zooplankton and phytoplankton in Banggai Sea waters. a positive trend was observed, although with very low $R^{2}$ value

The result of correlation and regression analysis (Figure 8) showed that phytoplankton community was not strong enough to act as main regulating factor for zooplankton patchiness in the Banggai Sea. But the positive correlation and regression trend (Figure 8) clearly showed an interaction between zooplankton and phytoplankton community, which should observed in the form of predator-prey relationship.

\subsection{Zooplankton Hotspot as Center for Marine Fishes Distribution in Banggai Sea}

It was not surprising that station 9, the hot spot of zooplankton abundance, has a unique community structure which very different from the others (Figure 5). This distinctive community structure probably occurred due to the mix of different water masses and the present of coastal front in station 9. This condition might be favorable for the growth of zooplankton and in the end it might also favorable for the growth of zooplanktivorous fishes in Banggai Sea. As widely known, zooplankton was very important component in marine food web that support the growth of fish community in the ecosystem (Nybakken and Bertness, 2005; Hsiao et al., 2011; Escribano et al., 2007). Thus one determining factors of commercial fisheries production in marine ecosystem was the production of pelagic zooplankton, the population fluctuations, and the community structure of zooplankton (Bednarski and MoralesRamirez, 2004). In some tropical areas, such as tropical Atlantic Ocean at West Africa, zooplankton was regarded as important food for tuna preys, thus it also regulating the abundance of tuna in the ocean (Champalbert et al., 2005). Based on result of this research, it was assumed that the hot spot area of zooplankton distribution might also become the hot spot area of fishes in Banggai Sea.

\section{CONCLUSSION}

From this research it can be concluded that patchiness in zooplankton spatial distribution was assumed related to the mixing of water masses from Moluccas Sea and Banda Sea. High abundance and unique zooplankton community structure in the strait between 
Liang and Labobo Island indicated that this area might be a hot spot of zooplankton in Banggai Sea.

\section{ACKNOWLEDGEMENTS}

This research was conducted during Banggai Sea Expedition, part of Transfer Knowledge program in 2012, which funded and supported by Research Center for Oceanography, Indonesian Institute of Sciences. We would like to give our great appreciation to all crew of Baruna Jaya VIII research vessel which facilitates this research and greatly assist us in sample collection during the expedition. We also express our great appreciation to Ms. Hikmah Thoha, M.Sc., which helped us in sample collecting. We also give our sincere gratitude to Ms. Nurul Fitriya, M.Sc., for the very helpful discussion on our research theme.

\section{REFERENCES}

Arinardi, O.H. 1997. Metode penelitian plankton bahari. In: Hutagalung, H.P., D. Setiapermana, dan S.H. Riyono (eds.). Metode analisis air laut, sedimen dan biota: Buku 2. Pusat Penelitian dan Pengembangan Oseanologi, Lembaga Ilmu Pengetahuan Indonesia. Jakarta. Hlm.: 143-152.

Asriyana dan Yuliana. 2012. Produktivitas perairan. PT. Bumi Aksara. Jakarta. Hlm.:70-82.

Baars, M.A., A.B. Sutomo, S.S. Oosterhuis, and O.H. Arinardi. 1990. Zooplankton abundance in the Eastern Banda Sea and Northern Arafura Sea during and after the upwelling season, August 1984 and February 1985. Netherlands J. of Sea Research, 25:527-543.

Bednarski, M. and A. Morales-Ramirez. 2004. Composition, abundance and distribution of macrozooplankton in Culebra Bay, Gulf of Papagayo, Pacific coast Costa Rica and its value as bioindicator of pollution. Revista de Biologia Tropical, 52:1-16.

Champalbert, G., M. Pagano, B. Kouame and V. Riandey. 2005. Zooplankton spatial and temporal distribution in a tropical oceanic area off West Africa. Hydrobiologia, 548: 251-265.

Cox, G.W. 1976. Laboratory manual of general ecology $3^{\text {rd }}$ ed. WmC. Brown Company Publishing. Iowa. $35 \mathrm{p}$.

Escribano, R., P. Hidalgo, H. Gonzalez, R. Giesecke, R. Riquelme-Bugueno, and K. Manriquez. 2005. Seasonal and inter-annual variation of mesozooplankton in the coastal upwelling zone off centralsouthern Chile. Progress in Oceanography, 75:470-485.

Gordon, A.L. and R.D. Susanto. 2001. Banda sea surface-layer divergence. Ocean Dynamics, 52:2-10.

Horne, A.J. and C.R. Goldman. 1994. Limnology $2^{\text {nd }}$ ed.. McGraw-Hill, Inc. California. USA. 433-455pp.

Hsiao, S., S. Ka, T. Fang and J. Hwang. 2011. Zooplankton assemblages as indicators of seasonal changes in water masses in the boundary waters between the East China Sea and the Taiwan Strait. Hydrobiologia, 10:1-14.

McAleece, N., J.D. Gage, J. Lambshead, and G.L.J. Peterson. 1997. Biodiversity professional statistical analaysis software. The Natural History Museum \& The Scottish Association or Marine Science. London. United Kingdom.

Neuman-Leitao, S., E.M.E. Sant'anna, L. M.D.O. Gusmao, D.A.D. Nascimento-Vieira, M.N. Paranagua, and R. Schwamborn. 2008. 
Diversity and distribution of the mesozooplankton in the tropical Southwestern Atlantic. J. of Plankton Research, 30:795-805.

Nontji, A. 2008. Plankton laut. LIPI Press. Indonesia. 331hlm.

Nybakken, J.W. and M.K. Bertness. 2005. Marine biology: an ecological approach $6^{\text {th }}$ ed. Pearson Education, Inc. San Fransisco. USA. 42-98pp.

Rakesh, M., A.V. Raman, and D. Sudarsan. 2006. Discriminating zooplankton assemblages in neritic and oceanic waters: a case for the northeast coast of India, Bay of Bengal. Marine Environmental Research, 61:93-109.

Riandey, V., G. Champalbert, F. Carlotti, I. Taupier-Letage, and D. ThibaultBotha. 2005. Zooplankton distribution related to the hydrodynamic features in the Algerian Basin (western Mediterranean Sea) in summer 1997. Deep-Sea Research, 52: 2029-2048.

Sprintall, J., S.E. Wijffels, R. Molcard, and I. Jaya. 2009. Direct estimates of the Indonesian throughflow entering the Indian Ocean: 2004-2006. J. of Geophysical Research, 114:1-19.

Semina, H.J. 1987. Using the standard microscope: treatment of an aliquot sample. In: Sournia (ed.). Phytoplankton manual. United Nations Educational, Scientific and Cultural Organization. France. $181 \mathrm{p}$.

Shirota, A. 1966. The plankton of south Vietnam: freshwater and marine plankton. Over. Tech. Coop. Agent. Japan. 419p.

Wickstead, J.H. 1976. The institute of biology's studies in biology no.
62: Marine Zooplankton. Edward Arnold Publisher Ltd. USA. 2224pp.

Yamaji, I. 1966. Illustration of the marine plankton of Japan. Hokusho. Japan. 369p. 